\title{
Production of biodiesel and catalysts for transesterification: A review
}

\author{
Sara P. Cuellar-Bermudez ${ }^{a}$, César Torres ${ }^{b}$, Diana L. Cárdenas-Chávez ${ }^{a}$, Fernando Toscano-Villicaña ${ }^{a}$, \\ Miguel A. Romero-Owaga ${ }^{\text {b }}$, Roberto Parra-Saldívar ${ }^{\mathrm{a}^{*}}$
}

${ }^{a}$ Cátedra de Bioprocesos Ambientales, Centro del Agua para América Latina y el Caribe, Tecnológico de Monterrey, Campus Monterrey, NL, México. ${ }^{b}$ Departamento de Ingeniería Química, Tecnológico de Monterrey, Campus Monterrey, NL, México.

*Email: r.parra@itesm.mx

Recibido 25 de Septiembre 2013; Aceptado el 30 Septiembre de 2013

\section{Resumen}

La actual demanda excesiva de energía, el agotamiento de los combustibles fósiles, aumento en los precios del petróleo y las restricciones ambientales han forzado a los países a investigar alternativas de energía renovable para reemplazar las fuentes tradicionales de energía. El biodiesel es un biocombustible producido a partir de aceites vegetales (comestibles y no comestibles) o grasas animales. Sin embargo, para convertirse en una alternativa viable debe competir económicamente con el diesel. Asimismo, el costo final del biodiesel (60-75\%) depende principalmente del precio de las materias primas utilizadas. En este trabajo se han descrito los factores importantes para la producctión de biodiesel, tales como tipo de catalizador (base, ácido o enzimas) y condiciones de reacción (transesterificación) para diferentes materias primas. Por ejemplo, el aceite de cocina usado representa una opción económica para la producción de biodiesel a pesar de su alto contenido de ácidos grasos libres. Adicionalmente, nuevas técnicas como catálisis heterogénea son evaluadas, ya que éstas han ganado importancia y difusión debido a su capacidad de reuso y regeneración del catalizador disminuyendo así los costos de producción y facilitando la purificación del biodiesel. Además, se describen otras tecnologías acopladas al proceso de producción de biodiesel tales como microondas, ultrasonido y metanol supercrítico.

Palabras clave: Biodiesel, tecnologías de producción, catalizadores, transesterificación, catálisis heterogénea.

\begin{abstract}
Current excessive demand for energy, fossil fuel depletion, increases in oil prices and environmental constraints have forced countries to investigate renewable energy alternatives to replace traditional energy sources. Biodiesel is a biofuel produced from vegetable oils (edible or non-edible) or animal fats. To become a viable alternative fuel and survive in the market, biodiesel should compete economically with diesel. Likewise, the end cost of biodiesel mainly depends on the price of the feedstocks that accounts for $60 \square 75 \%$ of the total cost of biodiesel fuel. Moreover, the reaction process for biodiesel production requires catalyst presence. In this paper, main factors as catalyst used for biodiesel production, and reaction (transesterification) conditions for different oil feedstocks have been described. As example, low-grade oil (waste cooking oil) represents an available and cheap feedstock for biodiesel production, although the high content of free fatty acids restrict the use of corrosive acid catalyst for high production yields. Basic catalyst is faster, cheaper and easier to carry out than acid catalyst, but high quality feedstocks are needed. In addition, new techniques as heterogeneous catalysis that facilitates the reuse and regenation of the catalyst, microwave, ultrasound and supercritical methanol have been described in this paper.
\end{abstract}

Key words: Biodiesel, production technologies, catalysts, transesterification, heterogeneous catalysis.

\section{Introduction}

The global energy crisis and political pressure to reduce the greenhouse gases (GHG) have attracted many researchers to find ways to reduce the emissions of $\mathrm{CO}_{2}$ and other GHG. Moreover, the reduction of crude oil reserves and difficulties in their extraction and processing has leaded an increase of oil cost. Nowadays, biofuels represent an important alternative to lead with these concerns. The term biofuel refers to liquid or gaseous fuels for the transport sector [1]. Biofuels have a positive impact in all economies, including social and sustainability development, GHG emissions reduction and regional development [2]. The principal biofuels are bioethanol, biodiesel, biohydrogen, and biogas [1]. The biofuels sector includes alcohols (derived from sugars fermentation or conversion of cellulosic biomass through a combination of hydrolysis and fermentation or gasification and synthesis), traditional biodiesel (mono-alkyl esters made from transesterification of vegetable or animal triglycerides), and synthesis fuels of alcohols and alkanes (gasoline, diesel, etc.) produced from gasification of biomass and Fischer-Tropsch synthesis or from others combined thermochemical processes [2]. Biodiesel has significant potential for use as an alternative fuel in compression 1 ignition (diesel) engines $[3,4]$. It is technically competitive with conventional petroleum derived diesel fuel and requires no changes in the fuel distribution infrastructure [5]. Biodiesel is also biodegradable, nontoxic and with a favorable combustion emission profile, producing much less carbon monoxide, sulfur dioxide and unburned hydrocarbons than petroleum-based diesel fuel [1, 610]. There are many types of biomass that have been proposed as biodiesel feedstock such as animal grease, vegetable oil (soybean, palm, rapeseed and jatropha), waste cooking oils and microalgae [9-12]. Among the biodiesel production methods [6,13,14] exist: (1) direct use of vegetable oil, although compared with 
petrodiesel has higher kinematic viscosity, low volatility, produces carbon deposits, thickening and gelling of the lubricating oil, and incomplete combustion; (2) microemulsions formed by a colloidal equilibrium dispersion of optically isotropic fluid microestructures with dimensions in the $1-150 \mathrm{~nm}$ range produced spontaneously from two immiscible liquids and one or more ionic or non-ionic amphiphiles. However the final product has a low cetane number, low energy content, and produces heavy carbon deposits; (3) pyrolysis or thermal cracking of biomass conversion by heat. The final fuel is chemically similar to petroleum derived gasoline and diesel fuel, but requires high energy input also has higher cost; (4) transesterification by reaction of triglycerides with an alcohol in presence of a catalyst producing fatty acid chains (biodiesel) and glycerol. Transesterification is the most common due to its simplicity and has been widely studied and industrially used.

\section{Experimental Section}

\section{Transesterification reaction}

Natural vegetable oils and animal fats are extracted to obtain crude oil or fat containing free fatty acids (FFA), phospholipids, sterols, water, odorants and other impurities [9]. Transesterification (also called alcoholysis) is the reaction of a fat or oil with an alcohol in presence of a catalyst to form esters and glycerol [9]. Methanol, ethanol, propanol, butanol are common alcohols used for transesterification reaction [9]. Limitations in the transesterification reaction are mainly due to oil impurities determining the reaction conditions (time and temperature) and catalyst nature (acid, basic, enzymes) $[15,16]$. Transesterification using methanol and ethanol produces Fatty Acid Methyl Esters (FAME) and Fatty Acid Ethyl Esters respectively. Methanol is preferred for been more economic and have lower reaction times compared with higher alcohol molecules. The stoichiometry of reaction requires $3 \mathrm{~mol}$ of methanol and $1 \mathrm{~mol}$ of triglyceride to give $3 \mathrm{~mol}$ of FAME and $1 \mathrm{~mol}$ of glycerol [17]. For a maximum performance, this ratio must be greater than the stoichiometric ratio since the reaction is reversible. Therefore, an excess of alcohol shift the equilibrium to the product side.

According to Vasudevan and $\mathrm{Fu}$ [2] the overall reaction can be divided into three consecutive reversible reactions where the triglyceride is converted stepwise to diglyceride, monoglyceride and finally glycerol [14]: (i) the triglyceride molecule reacts with alcohol to produce an alkyl ester molecule and a diglyceride, (ii) the diglyceride produced reacts with other alcohol molecule to produce a monoglyceride and a alkyl ester and (iii) the monoglyceride further reacts with the residual alcohol molecule to produce alkyl ester and glycerol (Fig. 1).

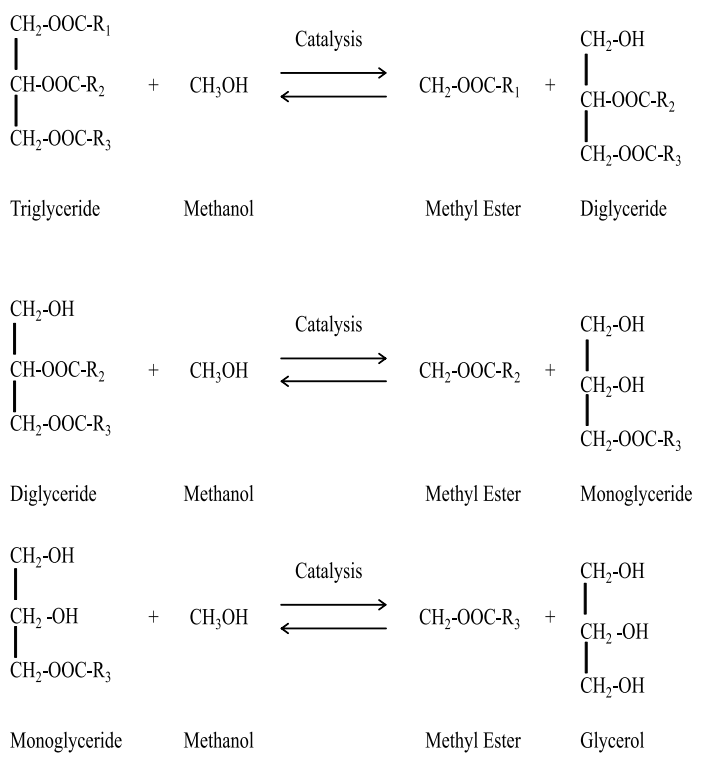

Figure 1. Consecutive reversible reactions of transesterification using methanol [2]. The reaction can take place with others alcohols in the formation of alkyl esters.

Vegetable oils and fats may contain small amounts of water and FFA. The production of FAME from FFA and alcohol in presence of acid catalyst is also known as esterification reaction (Fig 2). However, FFA can react with basic catalysts and a saponification reaction occurs, which is undesirable due to it decreases biodiesel production (Fig. 2)

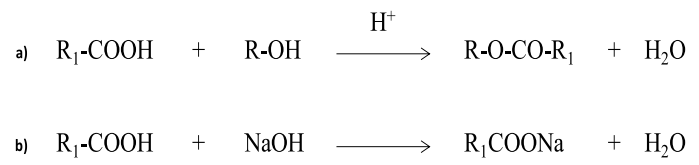

Figure 2. Esterification (a) and saponification (b) reactions from FFA [18].

A successful transesterification reaction produces two liquid phases: ester (biodiesel) and crude glycerol [2]. The glycerol phase is much denser than the biodiesel phase and settles at the bottom of the reaction vessel after several hours (1-19), allowing it to be separated from the biodiesel phase [13]. However, both biodiesel and glycerol phases are contaminated with unreacted catalyst, alcohol and oil after the reaction is over. Generally, three main approaches are adopted for purifying biodiesel: water washing, dry washing and membrane extraction. Water washing is the most common for its low price and effective contaminants removal [13]. Impurities in the biodiesel phase causes low efficient performance in motors, for example the presence of high level of alcohol in biodiesel causes accelerated deterioration of natural rubber seals and gaskets. Therefore, the control of alcohol content is required [18]. 
Important parameters for transesterification reaction

The transesterification reaction presents critical parameters that strongly influence the final biodiesel yield. The most significant variables are:

\section{Acyl-Acceptors}

Methanol is the most common alcohols used in the transesterification reaction. Current production of methanol mainly depends on fossil fuels and its high toxicity involves a potential health risk during manufacture [2]. Methanol production process includes distillation of liquid from wood or coal pyrolysis, gaseous products from biomass gasification, synthetic gas from biomass and coal, and natural gas or petroleum [19]. On the other hand, ethanol is derived from renewable biomass with a higher hydrophobicity and energy content than methanol [2]. But, the yield of fatty acid ethyl esters is less compared to methyl esters as well as separation of glycerol is the main constrains in the process of ethanolysis [19]. Ethanol can be also produced from: fermentation of sugars and starches, bioconversion of cellulosic biomass, hydration of alkanes, synthesis from petroleum or coal [19].

\section{FFA and water content}

Commercial crude oils and fats contain free fatty acids in different percentages. Free fatty acids and water produce adverse effects in conventional oils, since their presence cause formation of soaps, consumes the catalyst, decreases catalyst efficiency and product quality resulting in a low conversion [20-22]. Water also caused soap formation generating an increase in viscosity, formation of gels and difficult separation of glycerol [9].

\section{Reaction temperature and time}

Transesterification occurs at various temperatures depending on the alcohol and oil used. As increase the temperature, increases the yield and the reaction time is reduced. It is recommended that the temperature does not exceed the boiling point of the alcohol [20-22]. Moreover, the greater reaction time, the reaction yield increases. This condition will depend on the catalyst and oil nature.

\section{Molar ratio alcohol/oil.}

According to the reaction stoichiometry, transesterification of triglycerides with alcohol requires a molar ratio of alcohol/oil of 3:1. Since transesterification reaction is reversible, the excess of alcohol displaces the equilibrium in the direction of formation of esters, therefore an excess of alcohol favors the formation of the products [17, 20-23]. On the other hand, an excessive amount of alcohol difficult the glycerol recovery, so the ideal alcohol/oil ratio has to be established empirically, considering each individual process [19].

\section{Type of catalyst.}

The catalyst has to be chosen according to the characteristics of the oil used (Table 1). If the oil has a high content of free fatty acids and moisture, it is recommended to use acid catalysts since base catalysis favors the formation of soaps. Transesterification reaction can take place in homogeneous or heterogeneous acid, basic or enzymatic media.

\section{Homogeneous acid catalyst}

The liquid acid-catalyzed transesterification process is not much popular as the base-catalyzed process. Homogeneous acid catalyzed reaction is about 400 times slower than the homogeneous base-catalyzed reaction, requires high ratio of alcohol/oil and corrosive reagents lead to corrosion [13, 16, 24-26]. However, acid catalyst has a big advantage; it produces bio-diesel from low-cost lipid feedstock generally associated with high FFA concentrations. In fact, acid catalysts can simultaneously catalyze both esterification and transesterification [23]. These reactions are generally catalyzed by acidic catalysts used to convert free fatty acids to esters or ester-soaps as a pretreatment for the raw materials that contain high amounts of free fatty acids [23]. The acid catalysts normally used are sulfuric acid, phosphoric acid, hydrochloric acid and sulfonic acid.

\section{Homogeneous base (alkali) catalyst}

In the alkali catalytic methanol transesterification method, the catalyst is dissolved into methanol by vigorous stirring in a small reactor [23]. FFA content should not exceed beyond a certain limit. In order to prevent saponification during the reaction, FFA and water content of the feed must be below $0.5-2 \%$ wt. and $0.05 \%$ wt. respectively [23]. Base catalyst reacts 400 times faster than acid catalyst and cheap regents as sodium or potassium hydroxide are normally used. These catalysts are relatively cheap and widely available. As disadvantages, the base catalyst is sensitive to FFA content in the oil and soap will be formed if the FFA content is more than $2 \%$ wt. causing yield and purification problems [14].

\section{Heterogeneous acid/base catalysts}

Catalysts in homogeneous reactions have the disadvantage that cannot be reused or regenerated, because the catalyst can be consumed in the reaction or catalyst separation from products is difficult and requires additional equipment resulting in higher production costs [27]. Thus, developing solid catalyst seems to be an opportunity to avoid problems associated with homogeneous catalyst. Metal oxides, alkali earth metal oxides (magnesium oxide, calcium oxide, strontium oxide) and transition metal oxides (zirconium oxide, titanium oxide and zinc oxide) are examples of heterogeneous catalyst [27-32]. Heterogeneous base catalysis allows an easy separation of catalyst from product, high possibility to reuse and regenerate the catalyst and faster reaction rate than acid catalyzed reaction. However, it is sensitive to FFA content, forming soaps with FFA higher than $2 \mathrm{wt} \%$. In contrast, heterogeneous acid catalyst has the advantage of react in presence of FFA and water in the oil. This method is preferred for low grade oil allowing easy separation of catalyst from product. High temperature, reaction time conditions and high alcohol to oil molar ratio are also required. Moreover catalyst synthesis procedures lead to higher cost. 
It is important to mention that not all the surface of a heterogeneous catalyst is active, generally small size are desired to maximize the exposure of the active centers. However, small and fragile solid materials production is difficult for industrial scale applications. Porous materials as zeolites, silica or activated carbon are used to extend the surface area of the catalyst. Moreover, cosolvents as tetrahydrofuran (THF), dimethyl sulfoxide (DMSO), n-hexane and ethanol are used to decrease diffusion limitations, promoting oil miscibility with methanol and accelerating the reaction rate [27]. Catalyst supports as alumina, zinc oxide and zirconium oxide are also used to provide higher surface area because the metal particles can be anchored in the pores [33].

\section{Enzymatic catalyst}

Biodiesel also may be produced by biocatalytic transesterification in the presence of an enzyme such as lipase. This process has many advantages over the conventional catalysts as the abscence of by-products, operation with moderate processing conditions (35-45 ${ }^{\circ} \mathrm{C}$ ) and reuse and regeneration of the catalyst. Moreover, the oil used can have impurities as FFA and water. However the enzymes are sensitive to high cuantity of alcohols resulting in very slow reaction rates and high cost $[2,14]$. Nevertheles, the addition of an organic solvent (hexane) in the reaction system enhances the solubility of oil and methanol in the solvent, limiting the concentration of methanol surrounding the enzyme [2].

Table 1. Catalysts used in biodiesel production [2, 23, 27]

\begin{tabular}{|c|c|c|c|c|c|c|c|}
\hline & \multicolumn{7}{|c|}{ Table 1. Catalysts used in biodiesel } \\
\hline & Catalyst & Oil & Alcohol & $\begin{array}{l}\text { Ratio } \\
\text { Alcohol/oil }\end{array}$ & $\begin{array}{l}\text { Reaction } \\
\text { conditions }\end{array}$ & $\begin{array}{l}\text { Time } \\
\text { (h) }\end{array}$ & Efficiency \\
\hline \multirow{7}{*}{$\begin{array}{l}\text { Heterogeneous } \\
\text { base catalyst }\end{array}$} & $\mathrm{KOH}$ on $\mathrm{MgO}$ & Canola & Methanol & $6: 1$ & $65^{\circ} \mathrm{C}$ & 9 & 0.95 \\
\hline & $\mathrm{CaO}$ on $\mathrm{SBA}-15$ & Sunflower & Methanol & $12: 1$ & $60^{\circ} \mathrm{C}$ & 5 & 0.95 \\
\hline & Activated $\mathrm{CaO}$ & Vegetable & Methanol & $14: 1$ & $50^{\circ} \mathrm{C}$ & 3 & $0.85-0.92$ \\
\hline & $\mathrm{ZnO}-\mathrm{La}_{2} \mathrm{O}_{3}$ & $\begin{array}{l}\text { Waste } \\
\text { cooking }\end{array}$ & Methanol & - & - & 1.5 & 0.9 \\
\hline & $\mathrm{ZnO} / \mathrm{KF}$ & Soybean & Methanol & $10: 1$ & $65^{\circ} \mathrm{C}$ & 9 & 0.87 \\
\hline & $\mathrm{Al}_{2} \mathrm{O}_{3} / \mathrm{KI}$ & Soybean & Methanol & $15: 1$ & - & 8 & 0.96 \\
\hline & $\mathrm{CaO}$ & $\begin{array}{l}\text { Waste } \\
\text { cooking }\end{array}$ & Methanol & $12: 1$ & $60^{\circ} \mathrm{C}$ & 1 & 0.66 \\
\hline \multirow{6}{*}{$\begin{array}{l}\text { Heterogeneous } \\
\text { acid catalysts }\end{array}$} & Zinc stearate silica gel & $\begin{array}{l}\text { Waste } \\
\text { cooking }\end{array}$ & Methanol & $18: 1$ & $200{ }^{\circ} \mathrm{C}$ & 10 & 0.98 \\
\hline & Sulfonated polystyrene & Soybean & Methanol & $100: 1$ & $64{ }^{\circ} \mathrm{C}$ & 18 & 0.94 \\
\hline & $\mathrm{ZrO}_{2} / \mathrm{SO}_{4}^{-2}$ & Palm & - & $6: 1$ & $200^{\circ} \mathrm{C}$ & 1 & 0.9 \\
\hline & $\mathrm{Al}_{2} \mathrm{O}_{3} / \mathrm{PO}_{4}^{-3}$ & Palm & Methanol & $5: 1$ & $200^{\circ} \mathrm{C}$ & 5 & 0.69 \\
\hline & Zeolite Y (Y756) & $\begin{array}{l}\text { Waste } \\
\text { cooking }\end{array}$ & Methanol & $6: 1$ & $460^{\circ} \mathrm{C}$ & 0.37 & 0.26 \\
\hline & $\mathrm{ZS} / \mathrm{Si}$ & $\begin{array}{l}\text { Waste } \\
\text { cooking }\end{array}$ & Methanol & $18: 1$ & $200^{\circ} \mathrm{C}$ & 5 & 0.98 \\
\hline \multirow{8}{*}{ Enzime } & C. cylindracea & Palm & Methanol & $3: 1$ & $37^{\circ} \mathrm{C}$ & 24 & 0.78 \\
\hline & C. antrarctica & Soybean & $\begin{array}{l}\text { Methyl } \\
\text { acetate }\end{array}$ & $12: 1$ & $40^{\circ} \mathrm{C}$ & 14 & 0.92 \\
\hline & P. fluorescens & Soybean & Ethanol & $3: 1$ & $70^{\circ} \mathrm{C}$ & 24 & 0.71 \\
\hline & P. cepacia & Jatropha & Ethanol & $4: 1$ & $50{ }^{\circ} \mathrm{C}$ & 8 & 0.98 \\
\hline & M. miehei & Castor & Methanol & $3: 1$ & $65^{\circ} \mathrm{C}$ & 8 & 0.90 \\
\hline & $\begin{array}{l}\text { Pseudomonas } \\
\text { fluorescens with } \\
\text { Polypropylene ep } 100 \text { as } \\
\text { carrier }\end{array}$ & Sunflower & $\begin{array}{l}\text { Methanol, } \\
\text { hexane as } \\
\text { solvent }\end{array}$ & $4.5: 1$ & $40^{\circ} \mathrm{C}$ & 24 & 0.95 \\
\hline & $\begin{array}{l}\text { Candida antarctica in } \\
\text { Celite-545 (carrier) }\end{array}$ & Jatropha & Porpan-2-ol & $4: 1$ & $50^{\circ} \mathrm{C}$ & 8 & 0.92 \\
\hline & $\begin{array}{l}\text { Candida antarctica in } \\
\text { Acrylic resin (carrier) }\end{array}$ & Soybean & Methanol & $4: 1$ & $50{ }^{\circ} \mathrm{C}$ & 12 & 0.80 \\
\hline \multirow{4}{*}{ Supercritical } & - & Sunflower & Methanol & $40: 1$ & $350^{\circ} \mathrm{C}, 200$ bar & 0.7 & 0.96 \\
\hline & - & Jatropha & Methanol & $40: 1$ & $350^{\circ} \mathrm{C}, 200$ bar & 0.7 & $>0.90$ \\
\hline & - & Soybean & Methanol & $40: 1$ & $310^{\circ} \mathrm{C}, 35 \mathrm{MPa}$ & 0.4 & 0.95 \\
\hline & - & Palm & Methanol & $45: 1$ & $300^{\circ} \mathrm{C}$ & 1 & 0.60 \\
\hline \multirow{3}{*}{ Microwave } & $\mathrm{KOH}$ & Cottonseed & Methanol & $6: 1$ & $\begin{array}{l}333{ }^{\circ} \mathrm{K}, 21 \% \text { of } \\
\text { an exit power of } \\
21 \mathrm{~W}\end{array}$ & $7 \mathrm{~min}$ & 0.92 \\
\hline & $\mathrm{KOH}$ & Rapeseed & Methanol & $6: 1$ & $\begin{array}{l}323{ }^{\circ} \mathrm{K}, 67 \% \text { of } \\
\text { an exit power of } \\
1200 \mathrm{~W}\end{array}$ & $5 \mathrm{~min}$ & 0.93 \\
\hline & $\mathrm{SiO}_{2} / 30 \% \mathrm{H}_{2} \mathrm{SO}_{4}$ & Castor & Ethanol & $6: 1$ & $220 \mathrm{~W}$ & $\begin{array}{l}25 \\
\min \end{array}$ & 0.95 \\
\hline \multirow{2}{*}{ Ultrasound } & $\mathrm{NaOH}$ & Soybean & Methanol & - & $24 \mathrm{kHz}, 60^{\circ} \mathrm{C}$ & $\begin{array}{l}20 \\
\min \end{array}$ & 0.97 \\
\hline & $\mathrm{C}_{2} \mathrm{H}_{5} \mathrm{ONa}$ & Fish & Ethanol & $6: 1$ & $24 \mathrm{kHz}, 60^{\circ} \mathrm{C}$ & $\begin{array}{l}60 \\
\min \end{array}$ & 0.98 \\
\hline
\end{tabular}




\section{Other Catalyst media}

Other technologies as microwaves, ultrasound and supercritical methanol have provided new options to produce biodiesel (Fig. 1) [23]: (1) Transesterification reaction in supercritical conditions can be completed in minutes, while the conventional catalytic transesterification takes several hours. The alcohol is not only a reactant but also an acid catalyst. As disadvantages, this technology has high price due to the high tempeature and pressure reaction conditions. (2) Microwave technology allows short reaction time with low alcohol and methanol ratio, and reduced energy consumption, but it is expensive for bid scale applications. (3) Ultrasound increases the chemical reaction speed and yield of the transesterification by increasing the mechanical energy for mixing and initiation of the reaction.

\section{Analytical methods for alkyl ester determination}

Since biofuels production process represented a fosil fuel replacement, the reaction process efficiency of biodisel production has to be monitorized. Some of the techniques commonly used are $[5,18]$ : (1) Gas chromatography (GC) with flame-ionization detectors (FID) or mass spectrometic detector; (2) High performance liquid chromatography method with pulsed amperometric detection, reverse phase HPLC, UV detection at $205 \mathrm{~nm}$, evaporative light scattering detection (ELSD) and atmospheric pressure chemical ionization mass spectrometry (APCI-MS); (3) Gel permiation chromatography method and (4) HNMR method and NIR spectroscopy. All this methods are mainly used to determine the reaction effiencies and the production of fatty acid alkyl esters.

\section{Additional specifications for biodiesel production} In order to produce a biodiesel of high quality, the following fatty acid profiles are desirable [37]: (1) Lowest possible saturated fatty acid levels (such as C16: 0 and C18: 0) for improved winter operability, (2) highest possible monounsaturated fatty acid levels (such as C18:1) for good stability and winter operability and (3) lowest possible polyunsaturated fatty acids levels (such as $\mathrm{C} 18: 3$ ) for increased oxidation stability.

The viscosity of biodiesel controls the characteristics of the injection from the diesel injector. This high viscosity level should be avoided for negative impacts on fuel injector system performance [18]. Furthermore, an optimal performance is affected during winter because biodiesel is mainly formed by saturated fatty acis. Cold filter plugging point (CFPP) of a fuel reflects its cold weather performance. At low operating temperature fuel may thicken and might not flow properly affecting the performance of fuel lines, fuel pumps and injectors. The Cloud Point (CP) is the temperature at which wax first becomes visible when the fuel is cooled and the Pour Point (PP) is the temperature at which the amount of wax out of solution is sufficient to gel the fuel, thus it is the lowest temperature at which the fuel can flow. Biodiesel has higher CP and PP compared to conventional diesel [19]. The cetane number measures how easily ignition occurs and the smoothness of combustion (high values are preferred) and this value affect combustion, stability, noise and emissions of carbon monoxide and hydrocarbons. Biodiesel has higher cetane number than conventional diesel fuel, which results in higher combustion efficiency [18]. The long term storage conditions depend on the fatty acid profile of the biodiesel. For example, to avoid crystals formation of biodiesel during storage time, the temperature of the biofuels should be kept between 7 and $10{ }^{\circ} \mathrm{C}$. Moreover poor stability can lead to an increased acid value and fuel viscosity and to the formation of gums and sediments. Therefore, an antioxidant additive is recommended if the duration of storing biodiesel is more than 6 months. Aluminum, steel, Teflon, and fluorinated polyethylene or polypropylene tanks are recommended for biodiesel storage [13].

\section{Conclusions}

Biofuels represent an actual and important research topic to solve the future fossil fuels scarcity. Moreover, different feedstocks and production process should be optimized in order to reach the sustainable development. This review showed different technologies used in the catalyst process production of biodiesel. From the different technologies production, heterogeneous catalyst seems to include all the benefits, being more efficient in the reuse and regeneration properties than homogeneous catalyst. However, biodiesel production process should be evaluated according to local materials availability, thus improving social and economic development.

\section{Acknowledgments}

The authors gratefully acknowledge the Water Center for Latin America and Caribbean and Tecnologico de Monterrey, Campus Monterrey for the support and assistance provided during this investigation.

\section{References}

1. Demirbas, A.; Demirbas M. Fatih, Algae Energy Algae as a New Source of Biodiesel. Springer-Verlag: London Limited, 2010; pp 19-20.

2. Palligarnai, T.; Vasuevan, Boyl Fu. Waste Biomass Valor. 2010, $1,47 \sqsubset 63$

3. Knothe, G.; Dunn, R. O.; Bagby, M. O. Biodiesel: The use of vegetable oils and their derivatives as alternative diesel fuels; Am. Chem. Soc. Symp. Series: Washington, 1997; pp $172 \square 208$.

4. Dunn, R. O.; Knothe, G.; Bagby, M. O. Recent Research Developments in Oil Chemistry: Kerala, 1997; pp 31-56.

5. Knothe, G. Trans ASAE. 2001, 44, 193-200.

6. Borges, M.E.; Díaz, L. Renew. Sust. Energy Rev. 2012, 16, 2839-2849.

7. Chen, Y; Xiao, B; Chang, J; Fu, Y; Lv, P; Wang, X. Energy Convers. Manage. 2009, 50, 668-673.

8. Guerreiro, L; Pereira, P.M.; Fonseca, I.M.; Martin-Aranda, R.M.; Ramos, A. M.; Dias, J. M. L.; Oliveira, R.; Vital, J. Catal. Today. 2010, 156, 191-197.

9. Ma, F.; Hanna, M. A. Bioresour. Technol. 1999, 70, 1-15.

10. Khan, S. A.; Rashmij; Hussain, M. Z.; Prasad, S.; Banerjee, U. C. Renew. Sust. Energy Rev. 2009, 13, 2361-2372. 
11. Brennan, L.; Owende, P. Renew. Sust. Energy Rev. 2009, 557-577.

12. Chisti, Y. Biotechnol. Adv. 2007, 25, 294-306.

13. Leung, D. Y. C.; Wu, X.; Leung, M. K. H. Appl. Energy. 2010, 87, 1083-1095.

14. Lam, M. K.; Lee, K. T.; Mohamed, A. R. Biotechnol. Adv. 2010, 28, 500-518.

15. González, A. F.; Jiménez, I. C.; Restrepo, S.; Gómez, J. M. Revista de Ingeniería. 2008, 70-82.

16. Math, M. C.; Kumar, S. P.; Chetty, S. V. Energy Sustain. Dev. 2010, 14, 339-345.

17. Vicente, G.; Martínez, M.; Aracil, J. Bioresour. Technol. 2004, 92, 297-305.

18. Meher, L. C.; Vidya, S. D.; Naik, S. N. Renew. Sust. Energy Rev. 2006, 10, 248-268.

19. Demirbas A. Prog. Energy Combust. Sci. 2005, 31, 466487.

20. Lee, J. S.; Saka, S. Bioresour. Technol. 2010, 101, 71917200.

21. Peng, B. X.; Shu, Q.; Wang, J. F.; Wang, G. R.; Wang, D. Z; Han, M. H. Process Saf. Environ. 2008, 86, 441-447.

22. Tan, K. T.; Lee, K. T.; Mohamed, A. R. Fuel Process. Technol. 2011, 92, 1905-1909.

23. Vyas, A. P.; Verma, J. L.; Subrahmanyam, N. Fuel. 2010, $89,1-9$.

24. Karmakar, A.; Karmakar, S.; Mukherjee, S. Bioresour. Technol. 2010, 101, 7201-7210

25. Helwani, Z.; Othman, M. R.; Aziz, N.; Fernando, W. J. N.; Kim, J. Fuel Process. Technol. 2009, 90, 1502-1514.
26. Atadashi, I. M.; Aroua, M. K.; Abdul Aziz, A. R; Sulaiman, N. M. N. Renew. Sust. Energy Rev. 2012, 16, 3275-3285.

27. Zabeti, M.; Wan Daud, W. M. A.; Aroua, M. K. Fuel Process. Technol. 2009, 90, 770-777.

28. Abreu, F.R.; Lima, D.G.; Hamú, E. H.; Einloft, S.; Rubim, J.C.; Suarez, P. A. Z. J. Am. Oil Chem. Soc. 2003, 80, 601-604.

29. Granados, M.L.; Poves, M. D. Z.; Alonso, D. M.; Mariscal, R.; Galisteo, F. C.; Moreno-Tost, R., Santamaría, J.; Fierro, J. L. G. Appl. Catal. B. 2007, 73, 317-326.

30. Wang, L.; Yang, J. Fuel. 2007, 86, 328-333.

31. Jitputti, J.; Kitiyanan, B., Rangsunvigit, P.; Bunyakiat, K.; Attanatho, L.; Jenvanitpanjakul, P. Chem. Eng. J. 2006, $116,61-66$.

32. Xie, W.; Huang, X. Catal. Letters. 2006, 107, 53-59.

33. Chorkendorff, I.; Niemantsverdriet, J. W. Concepts of Modern Catalysis and Kinetics, Wiley-VCH: Germany, 2003; pp 6-8.

34. Kiss, A. A.; Dimian, A. C.; Rothenberg, G. Adv. Synth. Catal. 2006, 348, 75-81.

35. Hattori, H. Chem. Rev. 1995, 95, 537-558

36. Narasimharao, K.; Mokhtar, M.; Basahel, S. N.; AlThabaiti, S. A. J. Mat. Sci. 2013, 48, 4274-4283.

37. Bart, J. C. J.; Palmeri, N.; Cavallaro, S. Biodiesel science and technology: from soil to oil. Woodhead Publishing Series in Energy: Cambridge, 2010. 